\title{
A PROPOSAL FOR TEACHING STATISTICS IN A CLASS OF NINTH YEAR OF ELEMENTARY SCHOOL WITH R-COMMANDER SOFTWARE
}

\author{
Luís Henrique Pio de Almeida, Aline Castello Branco Mancuso and Luciana Neves Nunes \\ Universidade Federal do Rio Grande do Sul, Brazil \\ Hospital de Clínicas de Porto Alegre, Brazil \\ lununes@mat.ufrgs.br
}

Several studies are being carried out in the Mathematic teaching area that indicating the need to introduce statistical concepts to increase the educational gains and improved training of students. In this context, this work shows a proposed activity for elementary school students. The main objective of this study was to plan and implement a didactic sequence, involving the use of RCommander program to stimulate students interest and the understanding of statistical concepts.

In terms of methodology, the maid research is classified as a case study in a public school in Porto Alegre (RS, Brazil), with a class of 25 ninth graders of elementary school. This proposal was planned to focus on research and followed the concepts of Mathematical Modeling. Data analysis was based on the principles of Statistics Teaching.

From the results it was possible to observe that the Mathematical Modeling combined with the use of R-Commander was a favorable combination for a good approach to Statistics teaching. The Mathematical Modeling, which was based this proposal, allowed students to think about reality through unforeseen situations that made possible the living of actual experiences. The software, much more than a simple tool was capable of breaking the static and monotonous view of some concepts, providing a dynamic and enabling students to further reflection on the concepts studied. The didactic proposal was able to arouse the interest and curiosity of the students and encouraged them to move. Students who previously showed apathetic in Mathematics classes were put on the move in search of the issues raised. Therefore it was observed that work with Mathematical Modeling in a research environment is a good alternative to overcome the limitation of lack of teaching statistical in primary school.

\section{REFERENCES}

Barbosa, J. C. (2001). Modelagem na Educação Matemática: contribuições para o debate teórico. Reunião anual da ANPED, 24, 1-15.

Brasil, Ministério da Educação e Desporto. Secretaria de ensino Fundamental. (1998). Parâmetros Curriculares Nacionais - Terceiro e quarto ciclos do Ensino Fundamental. Matemática. Brasília. DF: MEC, DEF.

Brasil, Ministério da Educação e Desporto. Secretaria de ensino Fundamental. (1998). Parâmetros Curriculares Nacionais - Terceiro e quarto ciclos do Ensino Fundamental. Matemática. Brasília. DF: MEC, DEF.

Ludke, M. \& André, M. E. D. A. (1986). Pesquisa em educação: Abordagens Qualitativas. São Paulo: EPU. Skovsmose, O. (2000). Cenários para investigação. Bolema - Boletim de Educação Matemática. Rio Claro, nº 14, p. 66 a 91. 